\title{
BMJ Open Views and experiences of people with acne vulgaris and healthcare professionals about treatments: systematic review and thematic synthesis of qualitative research
}

\author{
Athena Ip (D) , ${ }^{1,2}$ Ingrid Muller (D) , ${ }^{1}$ Adam W A Geraghty (D) , ${ }^{1}$ Duncan Platt, ${ }^{1}$ \\ Paul Little (D) , ${ }^{1}$ Miriam Santer ${ }^{1}$
}

To cite: Ip A, Muller I, Geraghty AWA, et al. Views and experiences of people with acne vulgaris and healthcare professionals about treatments: systematic review and thematic synthesis of qualitative research. BMJ Open 2021;11:e041794. doi:10.1136/ bmjopen-2020-041794

- Prepublication history and supplemental material for this paper is available online. To view these files, please visit the journal online (http://dx.doi. org/10.1136/bmjopen-2020041794).

Received 18 June 2020 Revised 05 January 2021 Accepted 14 January 2021

D) Check for updates

(c) Author(s) (or their employer(s)) 2021. Re-use permitted under CC BY-NC. No commercial re-use. See rights and permissions. Published by BMJ.

${ }^{1}$ School of Primary Care, Population Sciences and Medical Education, Faculty of Medicine, University of Southampton, Southampton, UK ${ }^{2}$ Faculty of Health and Medical Sciences, School of Health Sciences, University of Surrey, Guildford, UK

Correspondence to Athena Ip; a.ip@soton.ac.uk

\section{ABSTRACT}

Objectives The objective of this study was to systematically review and synthesise qualitative papers exploring views and experiences of acne and its treatments among people with acne, their carers and healthcare professionals (HCPs).

Design Systematic review and synthesis of qualitative papers.

Methods Papers were identified through Medline, EMBASE, PubMed, PsychINF0 and CINAHL on 05 November 2019, forward and backward citation searching, Google Scholar and contacting authors. Inclusion criteria were studies reporting qualitative data and analysis, studies carried out among people with acne, their carers or HCPs and studies comprising different skin conditions, including acne. The title and abstracts of papers were independently screened by three researchers. Appraisal was carried out using the adapted Critical Appraisal Skills Programme tool. Thematic synthesis was used to synthesise findings.

Results A total of 20 papers were included from six countries. Papers explored; experiences living with acne, psychosocial impact of acne, views on causation of acne, perceptions of acne treatments, ambivalence and ambiguity in young people's experience of acne and HCPs' attitudes towards acne management. Findings suggest that people often viewed acne as short-term and that this had implications for acne management, particularly long-term treatment adherence. People often felt that the substantial impact of acne was not recognised by others, or that their condition was 'trivialised' by HCPs. The sense of a lack of control over acne and control over treatment was linked to both psychological impact and treatment adherence. Concerns and uncertainty over acne treatments were influenced by variable advice and information from others.

Conclusions People need support with understanding the long-term management of acne, building control over acne and its treatments, acknowledging the impact and appropriate information to reduce the barriers to effective treatment use.

PROSPERO registration number CRD42016050525.
Strengths and limitations of this study

- This synthesis of qualitative studies provides a broader understanding around perceptions of acne and acne treatments than any single study, which can inform barriers and facilitators to treatment adherence.

- The search strategy was comprehensive and used the Information Specialists' Sub-Group search filter resource to ensure that all relevant terms were covered.

- The methods were robust, including three researchers screening all papers identified from database searches, independent quality appraisal of publications and a team approach to developing codes, themes and model to best reflect the data.

- The review was limited by gaps in the evidence base, which helps highlight future areas for further qualitative research.

\section{INTRODUCTION}

Acne vulgaris is a common skin condition worldwide. ${ }^{1}$ It can have a substantial impact on quality of life both physically and psychologically. ${ }^{2}$ Treatments for mild to moderate acne are topical preparations including topical retinoids or adapalene, topical antibiotics, combination topicals and azelaic acid. ${ }^{3}$ If these are not effective, oral antibiotics are prescribed or, in women, combined oral contraception or cocyprindiol. More severe acne is treated with oral isotretinoin. ${ }^{34}$

Quantitative research has found that adherence to acne treatments is poor. ${ }^{5}$ This is primarily the case for topical treatments for reasons including side effects, young age and forgetfulness. ${ }^{6}$ While quantitative research is useful for determining the prevalence and common reasons given for nonadherence, qualitative research is essential 
for understanding people's views and perceptions around treatments and more fully understand barriers and facilitators to treatment adherence.

By synthesising qualitative research on acne, we can generate new understandings that go beyond the primary studies. ${ }^{7}$ This is useful for informing future research and for developing interventions to support people in effectively managing their condition.

The aim of this systematic review was to identify and synthesise qualitative papers exploring views and experiences of acne and its treatments among people with acne, their carers and healthcare professionals (HCPs).

\section{METHODS}

The Enhancing transparency in reporting the synthesis of qualitative research statement was used to facilitate appropriate reporting for this synthesis of qualitative studies. ${ }^{8}$

\section{Search strategy}

Five databases were searched on 05 November 2019 using a comprehensive search strategy: Medline (19462019), EMBASE (1974-2019), PubMed (1996-2019), PsychINFO (1806-2019) and CINAHL (1981-2019). Databases were chosen to ensure that literature on nursing, social science, psychology and medicine were searched as comprehensively as possible. Other resources included backward and forward citation searching using Google Scholar, contacting authors of included papers regarding other articles or when full texts were unavailable.

The search strategy was developed through discussions with coauthors and a medical librarian at the University of Southampton. Searching for qualitative literature can be difficult and that is why we included a librarian and used the Information Specialists' Sub-Group search filter resource to ensure that all relevant terms related to acne and qualitative research were covered (see online supplemental material A for the list of search terms). We defined qualitative as papers presenting qualitative method of data collection and analysis as well as presenting qualitative data (quotes). There were no date or language restrictions.

Eligible papers reported on studies that used qualitative methods of data collection and analysis, presented qualitative data either standalone or distinct part of a mixed-methods study, included people with acne, HCPs treating acne or carers/parents of children with acne and studies that considered more than one skin condition that included acne.

\section{Selection process}

Three independent researchers screened the title and abstracts of the papers (AI, DP and IM). AI conducted the full-text screening of eligible papers and any uncertainties were discussed with coauthors.

\section{Quality appraisal}

An adapted version of the Critical Appraisal Skills Programme tool was used to provide an indication of strengths and weaknesses of the qualitative papers. ${ }^{9}$ All papers were included regardless of quality. Papers were appraised by AI, and other members of the research team (AWAG, MS and IM) independently appraised a third of papers each. Disagreements in quality assessment were resolved through discussion.

\section{Data extraction}

Study characteristics extracted from each paper included: author(s), country, year of publication, focus, participants, skin conditions, data collection, methodology, analysis and key themes presented by the author. The papers were repeatedly read by AI to ensure that all quotes and relevant text under the 'results' or 'findings' were extracted onto NVivo V.11 software to manage and code the data. ${ }^{10}$

\section{Synthesis of findings}

A thematic synthesis was carried out involving three stages. ${ }^{7}$ First AI carried out line-by-line coding of relevant text (quotes or authors' descriptions). Next, the free codes were organised to develop descriptive themes across studies. A coding manual was produced to facilitate the systematic coding of the data. The themes identified were deliberated with IM, MS, AWAG and PL and any discrepancies were discussed until the agreement was reached. The third stage involved 'going beyond' the data to develop analytical themes that generate additional understanding from synthesising original studies. Analytical themes were produced through team discussions and a model was developed showing the interrelationship between themes and their association with treatment initiation (decision to start treatment) and adherence.

\section{Patient and public involvement}

No patients were involved in carrying out this systematic review. Following publication, results will be disseminated through lay summary and social media.

\section{RESULTS}

The database search identified 2931 records and seven papers were found through other resources (2519 after removing duplicates). After eligibility screening, 20 papers were included in the synthesis (figure 1).

\section{Study characteristics}

The included studies were relatively heterogeneous, primarily exploring the following topics: experiences living with acne, psychosocial impact of acne, complementary and alternative medicines (CAM), sexual life and acne, patients' relationships with their doctors, views on causation of acne, perceptions of acne treatments, ambivalence and ambiguity in young people's experience of acne and HCPs' attitudes towards acne management. Methods of data collection included face-to-face, video or telephone interviews, written interviews online 


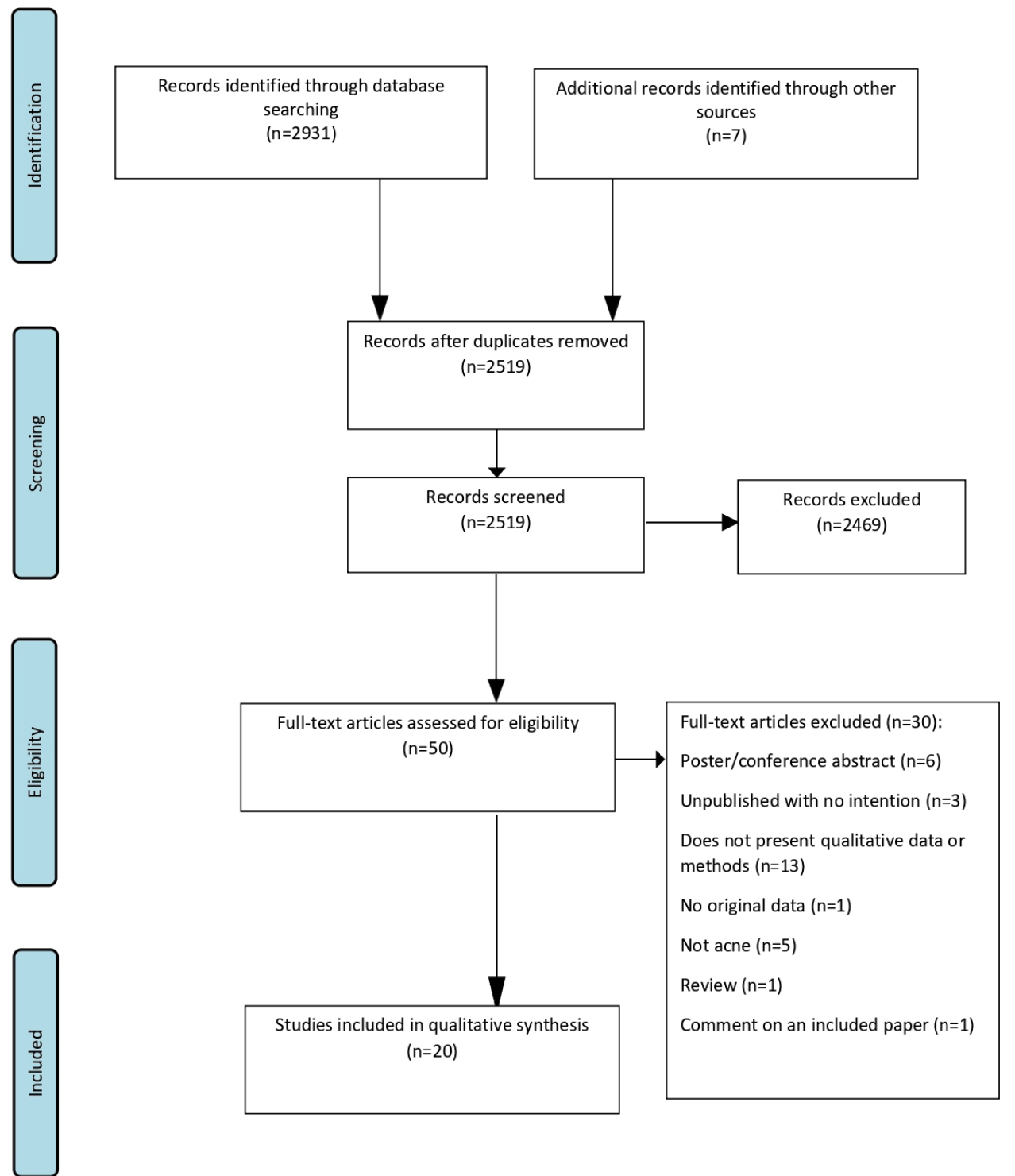

Figure 1 PRISMA flow diagram of search strategy and included papers.

and searching online discussion forums. Studies were carried out in India, US, UK, Australia, Italy and Germany (table 1).

\section{Quality appraisal results}

The overall quality of the papers varied with longer articles providing more information for the checklist. Many of the studies did not explore reflexivity of the researcher in terms of their disciplinary knowledge and epistemological position. In addition, many of the papers did not include participant characteristics when presenting quotes. Some papers did not explicitly state the qualitative approach or a recognised approach to analysis. One paper reported findings from a commercial trial that could result in bias and therefore conclusions from this study should be drawn with caution. ${ }^{11}$

\section{Synthesis of results}

Four overarching analytical themes were further developed from descriptive themes generated in the line-by-line coding: (1) People with acne tended to view their condition as short-term, (2) impact of acne not recognised by HCPs, others or self, (3) people wanted to have a sense of control over acne treatments and acne and (4) a range of barriers to acne treatments and strategies to help cope with acne. Figure 2 presents how the analytical and descriptive themes influence people's initiation and adherence to acne treatment. Table 2 presents a checklist of the studies that reported on each analytical theme. Example quotes or authors' description of quotes are presented in table 3. General practitioners' (GPs) views and perceptions are summarised separately as only one paper reported on this.

\section{Acne is viewed as short-term}

People with acne often seemed to view their condition as short-term and not requiring long-term treatment. Study participants commonly seemed to have little initial concern over their acne as they expected to 'grow out 
Table 1 Study characteristics of papers included in the synthesis

\begin{tabular}{|c|c|c|c|c|c|}
\hline $\begin{array}{l}\text { Study } \\
\text { (country) }\end{array}$ & Focus & Participants (sampling) & $\begin{array}{l}\text { Skin } \\
\text { condition(s) }\end{array}$ & $\begin{array}{l}\text { Data collection, } \\
\text { methodology and } \\
\text { analysis }\end{array}$ & $\begin{array}{l}\text { Key themes presented by } \\
\text { author }\end{array}$ \\
\hline McNiven $^{12}$ UK & $\begin{array}{l}\text { Ambivalence and } \\
\text { ambiguity in young } \\
\text { people's experiences } \\
\text { of acne }\end{array}$ & $\begin{array}{l}25 \text { participants aged } \\
13-25 \text { years } \\
\text { Primary care, } \\
\text { secondary care, patient } \\
\text { representative groups, } \\
\text { universities, colleges, } \\
\text { schools and social media } \\
\text { platforms }\end{array}$ & Acne & $\begin{array}{l}\text { In-depth qualitative } \\
\text { interviews } \\
\text { Coding reports were } \\
\text { analysed conceptually } \\
\text { by the author using } \\
\text { a mind-mapping } \\
\text { technique }\end{array}$ & $\begin{array}{l}\text { Differences and } \\
\text { ambiguities: } \\
\text { understandings held about } \\
\text { acne causes: negotiating } \\
\text { connotations; a medical } \\
\text { concern? Preferentially } \\
\text { positioning 'acne' or } \\
\text { 'spots'; and other people } \\
\text { and health contexts: } \\
\text { making comparisons }\end{array}$ \\
\hline $\begin{array}{l}\text { Magin et al }{ }^{13} \\
\text { Australia }\end{array}$ & $\begin{array}{l}\text { Views about the } \\
\text { causes of acne and } \\
\text { implications for acne } \\
\text { management }\end{array}$ & $\begin{array}{l}26 \text { participants with acne } \\
\text { (13-52 years) } \\
\text { Primary care, secondary } \\
\text { care and community } \\
\text { advertising }\end{array}$ & Acne & $\begin{array}{l}\text { Semistructured } \\
\text { interviews } \\
\text { Grounded theory } \\
\text { approach }\end{array}$ & $\begin{array}{l}\text { Beliefs regarding acne } \\
\text { causation; implications } \\
\text { of these beliefs for acne } \\
\text { management }\end{array}$ \\
\hline $\mathrm{KoO}^{15}$ USA & $\begin{array}{l}\text { Psychological impact } \\
\text { of acne }\end{array}$ & Not stated & Acne & $\begin{array}{l}\text { Interviews } \\
\text { Not labelled }\end{array}$ & $\begin{array}{l}\text { The psychosocial effect; } \\
\text { acne and functional status }\end{array}$ \\
\hline $\begin{array}{l}\text { Fabbrocini et al }{ }^{16} \\
\text { UK, Italy, and } \\
\text { Germany }\end{array}$ & $\begin{array}{l}\text { Impact of acne and } \\
\text { attributes to topical } \\
\text { treatments }\end{array}$ & $\begin{array}{l}34 \text { adolescents aged } \\
12-17 \text { years and } 16 \text { adults } \\
\text { aged } 18-47 \text { years with } \\
\text { moderate-severe acne } \\
\text { who were currently/ } \\
\text { recently prescribed topical } \\
\text { treatment } \\
\text { Recruited through a } \\
\text { specialist recruitment } \\
\text { panel }\end{array}$ & Acne & $\begin{array}{l}\text { In-depth, semi- } \\
\text { structured telephone } \\
\text { interviews } \\
\text { Thematic analysis }\end{array}$ & $\begin{array}{l}\text { Impact on their quality of } \\
\text { life; attributes of topical } \\
\text { treatments }\end{array}$ \\
\hline $\begin{array}{l}\text { Magin et al }{ }^{18} \\
\text { Australia }\end{array}$ & $\begin{array}{l}\text { Psychological impact } \\
\text { of acne }\end{array}$ & $\begin{array}{l}\text { Same participants as } \\
\text { reference. }^{13}\end{array}$ & Acne & $\begin{array}{l}\text { Semistructured } \\
\text { interviews } \\
\text { Grounded theory } \\
\text { approach }\end{array}$ & $\begin{array}{l}\text { Self-perception and } \\
\text { social anxiety; central } \\
\text { theme: appearance, } \\
\text { depression and anxiety; } \\
\text { and consequences of the } \\
\text { effects of acne; moderating } \\
\text { factors }\end{array}$ \\
\hline $\begin{array}{l}\text { Santer et al }{ }^{19} \text { UK } \\
\text { (Forum users in and } \\
\text { outside the UK) }\end{array}$ & $\begin{array}{l}\text { Views and } \\
\text { experiences of oral } \\
\text { antibiotics for acne } \\
\text { and advice shared } \\
\text { among messages } \\
\text { posted on online } \\
\text { forums }\end{array}$ & $\begin{array}{l}\text { Forums including } 65 \\
\text { discussions among } 294 \\
\text { participants discussing } \\
\text { oral antibiotics }\end{array}$ & Acne & $\begin{array}{l}\text { Systematic search } \\
\text { for online discussion } \\
\text { forums on acne (four } \\
\text { forums identified) } \\
\text { Thematic analysis }\end{array}$ & $\begin{array}{l}\text { Perception around } \\
\text { effectiveness and } \\
\text { appropriateness of oral } \\
\text { antibiotics for acne; } \\
\text { adverse effects with } \\
\text { antibiotics; variable advice } \\
\text { and experiences in acne } \\
\text { severity; and delay in onset } \\
\text { of action of oral antibiotics }\end{array}$ \\
\hline
\end{tabular}

Continued 
Table 1 Continued

\begin{tabular}{|c|c|c|}
\hline $\begin{array}{l}\text { Study } \\
\text { (country) }\end{array}$ & Focus & Participants (sampling) \\
\hline Skaggs et al ${ }^{11}$ USA & $\begin{array}{l}\text { Experience using } \\
\text { an acne treatment } \\
\text { (topical) }\end{array}$ & $\begin{array}{l}27 \text { young adults with acne } \\
(15-21) \\
\text { Single centre (either } \\
\text { primary or secondary } \\
\text { care) }\end{array}$ \\
\hline $\begin{array}{l}\text { Pruthi and } \mathrm{Babu}^{20} \\
\text { India }\end{array}$ & $\begin{array}{l}\text { Physical and } \\
\text { psychosocial impact } \\
\text { of acne in adult } \\
\text { females }\end{array}$ & $\begin{array}{l}11 \text { women, adult } \\
\text { participants with acne } \\
(18-25) \\
\text { Primary and secondary } \\
\text { care }\end{array}$ \\
\hline $\begin{array}{l}\text { Jowett and Ryan }{ }^{21} \\
\text { UK }\end{array}$ & $\begin{array}{l}\text { Impact of acne in } \\
\text { terms of occupational, } \\
\text { social and emotional } \\
\text { functioning }\end{array}$ & $\begin{array}{l}30 \text { participants with acne } \\
\text { aged } 16-79 \text { years } \\
\text { Secondary care (invited } \\
\text { by letter) }\end{array}$ \\
\hline $\begin{array}{l}\text { Magin et } a l^{22} \\
\text { Australia }\end{array}$ & $\begin{array}{l}\text { Impact of the media } \\
\text { on people with acne, } \\
\text { psoriasis and atopic } \\
\text { eczema }\end{array}$ & $\begin{array}{l}26 \text { patients with acne, } \\
29 \text { with psoriasis and } \\
7 \text { with atopic eczema } \\
\text { (13-73years) } \\
\text { Primary care, secondary } \\
\text { care and community } \\
\text { advertising }\end{array}$ \\
\hline $\begin{array}{l}\text { Magin et } \mathrm{al}^{23} \\
\text { Australia }\end{array}$ & $\begin{array}{l}\text { Impact of acne, } \\
\text { psoriasis and atopic } \\
\text { eczema on sexual } \\
\text { functioning and sexual } \\
\text { relationships }\end{array}$ & $\begin{array}{l}\text { Same participants as } \\
\text { reference. }{ }^{22}\end{array}$ \\
\hline $\begin{array}{l}\text { Magin et } a l^{24} \\
\text { Australia }\end{array}$ & $\begin{array}{l}\text { Impact of acne, } \\
\text { psoriasis and atopic } \\
\text { eczema in their } \\
\text { experience of teasing } \\
\text { and bullying }\end{array}$ & $\begin{array}{l}\text { Same participants as } \\
\text { reference. }\end{array}$ \\
\hline
\end{tabular}

Study
(country)

Skaggs et al ${ }^{11}$ USA Experience using an acne treatment (topical) of acne in adult females social and emotional and bullying
Data collection, methodology and Key themes presented by analysis author

Video interviews Not labelled

Symptoms; self-perception social placement; and perception of control

Acne

Semi-structured clinical interview and openended questions Not labelled

Acne, $\quad$ Semistructured

psoriasis and interviews atopic eczema Not labelled

\section{Acne, Semistructured} psoriasis and interviews atopic eczema Thematic analysis

psoriasis and interviews

atopic eczema Thematic analysis and grounded theory approach

Acne, Semistructured psoriasis and interviews atopic eczema Analytic induction method and modified grounded theory approach

\begin{tabular}{|c|c|c|c|c|c|}
\hline $\begin{array}{l}\text { Prior and } \\
\text { Khadaroo }^{25} \text { UK }\end{array}$ & $\begin{array}{l}\text { The meaning of living } \\
\text { with visible acne }\end{array}$ & $\begin{array}{l}11 \text { young adults with } \\
\text { mild-moderate facial acne } \\
\text { (18-22) at university } \\
\text { Snowball sampling and } \\
\text { email to different courses }\end{array}$ & Facial acne & $\begin{array}{l}\text { Interviews } \\
\text { Thematic analysis }\end{array}$ & $\begin{array}{l}\text { Coping strategies; } \\
\text { comparisons to earlier } \\
\text { self; advice and practical } \\
\text { support from family; and } \\
\text { gender and acne }\end{array}$ \\
\hline $\begin{array}{l}\text { Magin et } a l^{26} \\
\text { Australia }\end{array}$ & $\begin{array}{l}\text { Experiences of } \\
\text { patients with acne, } \\
\text { psoriasis or atopic } \\
\text { eczema in their } \\
\text { relationships with their } \\
\text { doctors }\end{array}$ & $\begin{array}{l}\text { Same participants as } \\
\text { reference. }^{22}\end{array}$ & $\begin{array}{l}\text { Acne, } \\
\text { psoriasis and } \\
\text { atopic eczema }\end{array}$ & $\begin{array}{l}\text { Semistructured } \\
\text { interviews } \\
\text { Thematic analysis and } \\
\text { modified grounded } \\
\text { theory approach }\end{array}$ & $\begin{array}{l}\text { Relationships with } \\
\text { GPs; relationships with } \\
\text { dermatologists }\end{array}$ \\
\hline $\begin{array}{l}\text { Ryskina et } \text { al }^{28} \\
\text { Large academic } \\
\text { health system in } \\
\text { the Philadelphia, } \\
\text { Pennsylvania, area. }\end{array}$ & $\begin{array}{l}\text { Experiences with } \\
\text { primary non- } \\
\text { adherence to } \\
\text { medications for } \\
\text { acne and to identify } \\
\text { physician-level factors } \\
\text { that may improve } \\
\text { adherence in this } \\
\text { population }\end{array}$ & $\begin{array}{l}\text { Interviews were } \\
\text { conducted with } 26 \\
\text { patients ( } 19 \text { women, } 6 \\
\text { aged }<26 \text { years, } 15 \text { aged } \\
26-40 \text { years, and } 5 \text { aged } \\
>40 \text { years) }\end{array}$ & Acne & $\begin{array}{l}\text { Structured interviews } \\
\text { Thematic content } \\
\text { analysis }\end{array}$ & $\begin{array}{l}\text { Barriers related to cost } \\
\text { of medication and } \\
\text { insurance coverage; } \\
\text { poor understanding } \\
\text { of prior authorisation } \\
\text { process; physician-patient } \\
\text { communication about } \\
\text { costs; solutions offered by } \\
\text { physicians: backup plan; } \\
\text { reservations regarding plan } \\
\text { of treatment }\end{array}$ \\
\hline
\end{tabular}


Table 1 Continued

\begin{tabular}{|c|c|c|c|c|c|}
\hline $\begin{array}{l}\text { Study } \\
\text { (country) }\end{array}$ & Focus & Participants (sampling) & $\begin{array}{l}\text { Skin } \\
\text { condition(s) }\end{array}$ & $\begin{array}{l}\text { Data collection, } \\
\text { methodology and } \\
\text { analysis }\end{array}$ & $\begin{array}{l}\text { Key themes presented by } \\
\text { author }\end{array}$ \\
\hline $\begin{array}{l}\text { Magin et } a l^{27} \\
\text { Australia }\end{array}$ & $\begin{array}{l}\text { Views and } \\
\text { experiences of } \\
\text { complementary and } \\
\text { alternative medicine } \\
\text { (CAM) therapies in } \\
\text { patients with acne, } \\
\text { psoriasis, or atopic } \\
\text { eczema }\end{array}$ & $\begin{array}{l}\text { Same participants as } \\
\text { reference. }^{22}\end{array}$ & $\begin{array}{l}\text { Acne, } \\
\text { psoriasis and } \\
\text { atopic eczema }\end{array}$ & $\begin{array}{l}\text { Semistructured } \\
\text { interviews } \\
\text { Thematic analysis }\end{array}$ & $\begin{array}{l}\text { CAM therapies in acne; } \\
\text { CAM therapies for psoriasis } \\
\text { and eczema }\end{array}$ \\
\hline $\begin{array}{l}\text { Magin et } a l^{29} \\
\text { Australia }\end{array}$ & $\begin{array}{l}\text { Views and } \\
\text { experiences of } \\
\text { isotretinoin }\end{array}$ & $\begin{array}{l}\text { Same participants as } \\
\text { reference. }\end{array}$ & Acne & $\begin{array}{l}\text { Semistructured } \\
\text { interviews } \\
\text { Thematic analysis }\end{array}$ & $\begin{array}{l}\text { Attitudes to 'medical' } \\
\text { treatments; perceptions } \\
\text { regarding isotretinoin } \\
\text { and adverse effects; } \\
\text { perceptions of } \\
\text { psychological effects; } \\
\text { and experiences of } \\
\text { psychological sequelae }\end{array}$ \\
\hline $\begin{array}{l}\text { Zureigat et } a l^{30} \\
\text { Australia }\end{array}$ & $\begin{array}{l}\text { General practitioners' } \\
\text { attitudes towards } \\
\text { acne management }\end{array}$ & $\begin{array}{l}20 \text { participants in total } \\
\text { consisting of GPs }(n=15) \\
\text { and general practice } \\
\text { registrars }(n=5)\end{array}$ & Acne & $\begin{array}{l}\text { Structured telephone } \\
\text { interviews with image } \\
\text { portraying a patient } \\
\text { Qualitative descriptive } \\
\text { methodology }\end{array}$ & $\begin{array}{l}\text { The GP experience } \\
\text { with acne patients; the } \\
\text { complexities of treatment } \\
\text { and referral; and moving } \\
\text { towards better patient } \\
\text { outcomes }\end{array}$ \\
\hline
\end{tabular}

GP, general practitioner.

of it' due to the perception that their acne was caused by puberty or other underlying causes/triggers. Studies showed how people expected treatment to cure their acne as opposed to control it, suggesting that they did not view their condition as requiring long-term management, with implications for initiating and adhering to treatment (table 3).
Identifying potential causes or triggers of acne

A common perception across studies was of viewing acne as a 'normal' part of adolescence. However, most participants seemed to have followed a more chronic course with some experiencing acne as an adult, which led to frustration and confusion. ${ }^{12-17}$ People looked for other possible causes including hygiene and diet with the hope



Figure 2 Model presenting the interrelationships between themes and how they influence treatment initiation and adherence. CAM, complementary and alternative medicine. 
Table 2 Analytical and descriptive themes with study reference

\begin{tabular}{|c|c|c|c|c|c|c|c|c|c|c|c|c|c|c|c|c|c|c|c|c|}
\hline \multirow{2}{*}{$\begin{array}{l}\text { Analytical and } \\
\text { descriptive themes }\end{array}$} & \multicolumn{20}{|c|}{ Study reference } \\
\hline & 12 & 13 & 14 & 15 & 16 & 17 & 18 & 19 & 11 & 20 & 21 & 22 & 23 & 24 & 25 & 26 & 28 & 27 & 29 & 30 \\
\hline \multicolumn{21}{|c|}{ Acne is viewed as short-term } \\
\hline $\begin{array}{l}\text { Identifying } \\
\text { potential causes } \\
\text { or triggers of acne }\end{array}$ & $\mathrm{P}$ & $P$ & $\mathrm{P}$ & $\mathrm{P}$ & $\mathrm{P}$ & $\mathrm{P}$ & & & & & & & & & & & & & & \\
\hline $\begin{array}{l}\text { Expectation that } \\
\text { treatment will cure } \\
\text { acne not control it }\end{array}$ & & & $\mathrm{P}$ & & & & & $\mathrm{P}$ & & & & & & & & & & & & \\
\hline \multicolumn{21}{|c|}{ Impact of acne not recognised } \\
\hline $\begin{array}{l}\text { Perceived physical } \\
\text { impact }\end{array}$ & $P$ & & & $\mathrm{P}$ & $\mathrm{P}$ & & $\mathrm{P}$ & & $\mathrm{P}$ & $\mathrm{P}$ & $\mathrm{P}$ & & & & & & & & & \\
\hline $\begin{array}{l}\text { Perceived } \\
\text { psychological } \\
\text { impact }\end{array}$ & $P$ & & & $\mathrm{P}$ & $\mathrm{P}$ & $\mathrm{P}$ & $\mathrm{P}$ & $\mathrm{P}$ & $\mathrm{P}$ & & $\mathrm{P}$ & $\mathrm{P}$ & $\mathrm{P}$ & & & & & & & \\
\hline $\begin{array}{l}\text { Perceived } \\
\text { social impact } \\
\text { (relationships/ } \\
\text { avoidance, } \\
\text { bullying and work/ } \\
\text { education) }\end{array}$ & $P$ & & & $\mathrm{P}$ & $\mathrm{P}$ & $P$ & $\mathrm{P}$ & & $\mathrm{P}$ & $\mathrm{P}$ & $\mathrm{P}$ & $\mathrm{P}$ & $\mathrm{P}$ & $\mathrm{P}$ & & & & & & \\
\hline Perceived blame & $P$ & & & & $\mathrm{P}$ & $\mathrm{P}$ & $\mathrm{P}$ & & & & & & & & $\mathrm{P}$ & & & & & \\
\hline $\begin{array}{l}\text { Perceived } \\
\text { trivialisation by } \\
\text { themselves, } \\
\text { healthcare } \\
\text { professionals and } \\
\text { others }\end{array}$ & $\mathrm{P}$ & & & $\mathrm{P}$ & $\mathrm{P}$ & & & $\mathrm{P}$ & & & $\mathrm{P}$ & & & & & $\mathrm{P}$ & $\mathrm{P}$ & & & $\mathrm{P}$ \\
\hline $\begin{array}{l}\text { Perceived control } \\
\text { over acne treatments } \\
\text { and acne }\end{array}$ & & $P$ & & & $\mathrm{P}$ & $P$ & $P$ & & $\mathrm{P}$ & & & & & & & & & $\mathrm{P}$ & & \\
\hline \multicolumn{21}{|c|}{ Barriers to acne treatments and use of coping strategies } \\
\hline $\begin{array}{l}\text { Concerns about } \\
\text { perceived adverse } \\
\text { effects and } \\
\text { effectiveness of } \\
\text { acne treatments }\end{array}$ & $P$ & & $\mathrm{P}$ & & $\mathrm{P}$ & & & $\mathrm{P}$ & $\mathrm{P}$ & & & & & & & & & $\mathrm{P}$ & $P$ & $\mathrm{P}$ \\
\hline $\begin{array}{l}\text { Desire to use CAM } \\
\text { and behavioural } \\
\text { strategies }\end{array}$ & & $P$ & & & & $\mathrm{P}$ & $\mathrm{P}$ & $\mathrm{P}$ & & & & & & & $\mathrm{P}$ & & $P$ & $\mathrm{P}$ & $\mathrm{P}$ & \\
\hline $\begin{array}{l}\text { Concealment/ } \\
\text { compensation }\end{array}$ & $P$ & & & & $\mathrm{P}$ & $\mathrm{P}$ & $P$ & & $\mathrm{P}$ & & & & & & $\mathrm{P}$ & & & & & \\
\hline $\begin{array}{l}\text { Variable advice } \\
\text { and support }\end{array}$ & & & & & $P$ & $P$ & & $\mathrm{P}$ & & & $P$ & & & & $P$ & & & & & \\
\hline $\begin{array}{l}\text { Comparisons to } \\
\text { earlier self and } \\
\text { others }\end{array}$ & $\mathrm{P}$ & & & & & $P$ & & $\mathrm{P}$ & & & & & & & $\mathrm{P}$ & & & & & \\
\hline
\end{tabular}

CAM, complementary and alternative medicine.

of 'curing' their acne. Hygiene concerns with regards to acne were related to dirty occupations, pollution, sweat, makeup and inadequate washing. ${ }^{13} 18$ Dietary considerations around acne included foods such as chocolate, soft drinks, fast foods, coffee, yeast and alcohol. ${ }^{13} 15$ Genetics and stress were less commonly mentioned by study participants. $^{13}$

Expectation that treatment will cure acne not control it

People expected medical treatments to 'cure' their acne, often feeling disappointed when this was not met. Participants described treatment as 'keeping their acne at bay', being only partially effective or not working at all. ${ }^{1419}$ This appeared to have implications for acne management, with disappointment leading to stopping treatment early or opting for alternative treatments in the absence of 'instant' results.

\section{Impact of acne not recognised}

People across studies experienced substantial impact because of their acne and were frustrated when they felt that this was not recognised by HCPs, friends and family. Physical, psychological and social impact were common 
and often led to problems with forming new relationships as well as maintaining current ones. Perceptions of blame from others and self-blame were apparent in the data, sometimes relating to the myths and misconceptions around acne causation. The perceived trivialisation by HCPs and work colleagues was common across the data and appeared to have implications for acne management including consulting behaviours.

\section{Perceived physical impact}

Physical impact was commonly discussed across studies and consisted of physical appearance, itching, quality of sleep, burning, scaring, redness and pain. ${ }^{11} 121516182021$

\section{Perceived psychological impact}

Study participants described the psychological impact of acne as feeling embarrassed, self-conscious, angry about the perceived cause of their acne, low self-esteem, suicidal, changes in personality and feeling ostracised from society due to the image of 'perfect skin' portrayed by the media. ${ }^{111215-1921-23}$

\section{Perceived social impact}

The social impact of acne was commonly reported across studies. People engaged in avoidance behaviours had a negative effect on relationships due to feeling self-conscious about their appearance ${ }^{11} 151618$ and a lack of confidence and worry about how they would be perceived. ${ }^{12} 1617202123$ Bullying and teasing appeared to increase psychological impact. ${ }^{15-18} 212224$ In terms of education and employment, participants reported missing school, feeling distracted, ${ }^{16}$ experiencing interpersonal difficulties (insensitive work colleagues and the public) and feeling self-conscious. ${ }^{151621}$

\section{Perceived blame}

A number of studies reported on feelings of self-blame and blame inflicted by others. ${ }^{12} 15161825$ Family members were sometimes perceived to blame participants if they had not 'grown out of it' as expected. When participants perceived their acne to be caused by diet or hygiene, this sometimes led to self-blame as these were within their control.

\section{Perceived trivialisation by HCPs, others and self}

Participants in several studies perceived acne to be "trivialised' by HCPs, for instance, leaving consultations feeling as though they were not listened to, feeling as though prescriptions were given without a second thought or feeling as though their condition was not taken seriously due to waiting for a referral to see a dermatologist. ${ }^{1516} 1926$ Participants also perceived trivialisation of acne among work colleagues, for instance, ignorance about acne and the need for appointments with HCPs, or around work absence. $^{21}$ There was an element of 'self-trivialisation' as participants in some studies described feeling reluctant to take on the 'sick role' mainly due to the stigma associated with acne, believing that their condition was a cosmetic issue rather than a medical one. ${ }^{12}$ As a result, 
people may try alternative treatments for their acne to avoid consulting the HCP.

\section{Perceived control over acne treatments and acne}

Across studies, there were two aspects of control: people's perceived control over acne and their control over treatment. $^{13} 18 \quad 27$ Their perceived control over treatment referred to people's beliefs in their chosen treatment rather than the control being in someone else's hands (HCP). For example, people in the studies opted for CAM and behavioural strategies, which they felt would alleviate the psychological impact of acne. Three studies reported on people's perceived control over their acne including feelings of powerlessness when treatments were perceived as ineffective. ${ }^{111617}$ One study (reporting findings from a commercial trial) found when people perceived increased control over their acne, this improved satisfaction with acne symptoms and alleviated the impact, regardless of acne improvement using a topical. ${ }^{11}$ Having control over treatment or acne appeared to help alleviate the psychological impact and improve adherence.

\section{Barriers to acne treatments and use of coping strategies}

Across studies, a key barrier to use of acne treatments was concern and uncertainty regarding their effectiveness, exacerbated by variable advice and support people received from others. Studies highlighted coping strategies discussed by participants, including concealment/ compensation (as described below) and making comparisons, which some participants found useful in the shortterm. Participants in many studies reported a preference for using CAM and behavioural strategies to address their acne. This could be viewed as a barrier to engaging with effective acne treatment or be perceived as a mechanism for coping through seeking control over the condition.

\section{Concerns about perceived adverse effects and effectiveness of acne treatments}

Concerns around topical treatments for acne included side effects (bleaching, irritation), strength of medication, speed of onset of action, what constituted appropriate application, storage, understanding different topicals and, as mentioned above, uncertainty around their effectiveness. ${ }^{141628}$ One study found effective use of topicals increased control over acne and reduced the psychological impact, although they did not explore perceptions of treatment ineffectiveness. ${ }^{11}$ Two studies highlighted how patients viewed oral isotretinoin as an effective treatment, although they expressed concerns around the treatment's side effects. ${ }^{1929}$ Perceived effectiveness of oral antibiotics varied as participants either found them effective, ineffective or partially effective where they worked temporarily. Barriers included delayed onset of action, perceived strength of treatment and adverse effects. ${ }^{141927}$ One study highlighted barriers such as cost of treatment and understanding processes used by health insurance companies. ${ }^{28}$ This study was carried out in USA and therefore, the barriers may not be relevant to the UK population.

\section{Desire to use CAM and behavioural strategies}

Some studies explored CAM and behavioural strategies for treating acne. CAM treatments included oils, citrus washes, aloe vera, tablets and vitamins. Participants reported a preference for CAM over medical treatments due to 'natural' ingredients and fewer adverse effects. ${ }^{27-29}$ Other reasons included sense of internal control and accessibility. ${ }^{18}$ Behavioural strategies included dietary manipulation, face washing and sun and sea exposure (less commonly mentioned). The belief that hygiene caused or exacerbated acne led participants to excessively wash or pick their acne to resolve the issue. ${ }^{13} 17-1925$ Dietary manipulation included avoiding foods deemed unhealthy and increasing water intake. ${ }^{13} 1819$

\section{Receiving variable advice and support about treatments and next steps}

Support from family members was appreciated and included encouragement to consult HCPs, suggestions about which products to try ${ }^{25}$ and some felt that humour about the condition or about their treatment (isotretinoin) from friends or family could make them feel less uncomfortable. ${ }^{1721}$ Participants felt that support from friends with acne were useful as they were able to relate to their situation ${ }^{16}$ and recommendations from friends such as products to try were often seen as useful particularly for male participants as some female participants found the advice unsolicited. ${ }^{21} 25$ Advice from online discussion forums was felt to be variable and often consisted of treatment recommendations or suggestions about consulting and navigating health services. ${ }^{19}$

\section{Concealment/compensation to cope with acne}

Strategies to cope with acne included concealment to take attention away from their acne such as changing clothing and hairstyles. ${ }^{11} 1617$ Applying makeup helped some participants cope emotionally, but for others, this emphasised their spots or wore off quickly and some viewed makeup as a cause of acne. ${ }^{12}{ }^{16}$ People reported compensating for their acne by doing activities including martial arts ${ }^{18}$ or losing weight. ${ }^{25}$

\section{Comparisons to earlier self and others}

Strategies including making comparisons to others or their earlier self were seen as a double-edged sword, whereby participants either felt better about their acne or felt worse, further exacerbating the psychological impact. $^{12171925}$ Participants made comparisons to other health conditions to validate the negative impact of acne or to feel grateful that things were not worse. ${ }^{12}$

\section{Key differences between GPs and patients' views and experiences}

One study highlighted GP's acknowledgement of the psychological impact as well as motivation to escalate severe cases for referrals. ${ }^{30}$ Research suggests that people's own assessment of acne severity differs from clinical assessments that may explain the contrasting views compared with people with acne in other studies, where 
they felt HCPs did not always take acne seriously. ${ }^{31-33}$ The current study also found that GPs were uncertain about topical treatment effectiveness, which they posited may be related to patients' treatment adherence. ${ }^{30}$

\section{DISCUSSION}

This systematic review and synthesis of qualitative research highlighted four analytical themes that influence treatment initiation and adherence. People often viewed acne as a short-term condition resulting in implications for self-management, particularly challenges to long-term treatment adherence. The impact of acne was substantial for participants in these studies and they were often frustrated when they perceived others to trivialise their condition. The importance of perceived control was highlighted, including the wish to feel in control of acne and the wish to control treatment. Having control over either one appeared to help alleviate the psychological impact and improve adherence. People had common concerns around treatments that were further influenced by variable advice.

\section{Strengths and weaknesses}

To our knowledge, this is the first systematic review and synthesis of qualitative papers on acne. It provides a comprehensive overview of people's views and experiences of acne and its treatments. We are confident that all relevant papers were included as three independent researchers were involved with screening the title and abstracts of papers. However, there is the possibility that we may have missed some studies because of our definition of qualitative and our inclusion/exclusion criteria whereby papers needed to present qualitative data, qualitative methods of data collection and analysis and provide a sufficient amount of information about the qualitative aspect if it was part of a wider study (eg, questionnaire development paper).

A potential weakness was the limited original research available as many of the included papers (eight) were from the same author. However, although these papers used the same sample, they focused on different research questions and looked at a breadth of peoples' experiences. We found areas that were underrepresented including HCPs' experiences treating acne, studies outside of UK and Australia and men with acne. The review was also restricted by the strengths and weaknesses present in the original papers.

\section{Comparison with other studies}

The findings are consistent with a review on the impact of eczema, psoriasis and epidermolysis bullosa, which found that people with chronic skin conditions experience negative social interactions. ${ }^{34}$

A review of qualitative studies on adherence to medicines found that people were reluctant to take medicines partly because of concerns over its use including adverse effects and perceived effectiveness. ${ }^{35}$ They also highlight how people wish to take control over their own treatment. ${ }^{35}$ These findings are consistent with those in this current study, which goes further by suggesting that an increased feeling of control was felt to alleviate the psychological impact and improve adherence.

Studies exploring other skin conditions (vitiligo, psoriasis and eczema) including a paper from this current synthesis have also found that patients feel their HCP trivialises their skin condition. ${ }^{26}$ 36-39 Through synthesising the studies, we have also highlighted the role of self-trivialisation in influencing people's consulting behaviours.

A quantitative systematic review of treatment adherence in acne found similar barriers around treatment adherence including adverse effects and delayed onset of action resulting in low adherence. ${ }^{6}$ Our qualitative synthesis explores this further, suggesting that treatment adherence is influenced by the variable advice received, desire to use CAM and behavioural strategies and perception around the causes of acne, particularly perception that it is a short-term condition.

\section{CONCLUSION}

This synthesis suggests the need for further research exploring HCPs' views and experiences with people with acne as certain areas (eg, perceived trivialisation, treatment choice, acne as a short-term condition and the psychological impact of acne) could be better addressed from both sides. The findings highlight the importance of communicating the long-term management of acne and the importance of control over acne or control over treatment. Further research around providing support for people with acne is needed, with emphasis on the need for mitigating psychological impact. Finally, people need reliable information about acne treatments including how to use them appropriately, time taken until onset of action and how to manage side effects to help them to effectively manage the condition.

\section{Twitter Ingrid Muller @IngridMuller7}

Contributors Conception, design and planning of the study were by Al, IM, AWAG, MS and PL as this was part of Al's PhD. Data curation, formal analysis and writing the original draft were by Al. Al screened all title and abstracts supported by IM and DP who carried out double screening of these articles. Full-text articles were screened by Al and any uncertainties were discussed with the team. Al carried out the quality appraisal on all papers and MS, AWAG and IM independently appraised a third each of these. All authors were involved with reviewing and editing the manuscript.

Funding This study is funded by the National Institute for Health Research (NIHR) School for Primary Care Research PhD Studentship for Al. The views expressed are those of the authors and not necessarily those of the NIHR or the Department of Health and Social Care.

Competing interests None declared.

Patient consent for publication Not required.

Provenance and peer review Not commissioned; externally peer reviewed.

Data availability statement All data relevant to the study are included in the article or uploaded as supplemental information.

Supplemental material This content has been supplied by the author(s). It has not been vetted by BMJ Publishing Group Limited (BMJ) and may not have been 
peer-reviewed. Any opinions or recommendations discussed are solely those of the author(s) and are not endorsed by BMJ. BMJ disclaims all liability and responsibility arising from any reliance placed on the content. Where the content includes any translated material, BMJ does not warrant the accuracy and reliability of the translations (including but not limited to local regulations, clinical guidelines, terminology, drug names and drug dosages), and is not responsible for any error and/or omissions arising from translation and adaptation or otherwise.

Open access This is an open access article distributed in accordance with the Creative Commons Attribution Non Commercial (CC BY-NC 4.0) license, which permits others to distribute, remix, adapt, build upon this work non-commercially, and license their derivative works on different terms, provided the original work is properly cited, appropriate credit is given, any changes made indicated, and the use is non-commercial. See: http://creativecommons.org/licenses/by-nc/4.0/.

\section{ORCID iDs}

Athena Ip http://orcid.org/0000-0002-8574-2569

Ingrid Muller http://orcid.org/0000-0001-9341-6133

Adam W A Geraghty http://orcid.org/0000-0001-7984-8351

Paul Little http://orcid.org/0000-0003-3664-1873

\section{REFERENCES}

1 Hay RJ, Johns NE, Williams HC, et al. The global burden of skin disease in 2010: an analysis of the prevalence and impact of skin conditions. J Invest Dermatol 2014;134:1527-34.

2 Williams HC, Dellavalle RP, Garner S. Acne vulgaris. The Lancet 2012;379:361-72.

3 Gollnick HP, Bettoli V, Lambert J, et al. A consensus-based practical and daily guide for the treatment of acne patients. $J$ Eur Acad Dermatol Venereol 2016;30:1480-90.

4 Zaenglein AL, Pathy AL, Schlosser BJ, et al. Guidelines of care for the management of acne vulgaris. J Am Acad Dermatol 2016;74:e33:945-73.

5 Dréno B, Thiboutot D, Gollnick H, et al. Large-Scale worldwide observational study of adherence with acne therapy. Int J Dermatol 2010;49:448-56.

6 Snyder S, Crandell I, Davis SA, et al. Medical adherence to acne therapy: a systematic review. Am J Clin Dermatol 2014;15:87-94.

7 Thomas J, Harden A. Methods for the thematic synthesis of qualitative research in systematic reviews. BMC Med Res Methodol 2008:8:45.

8 Tong A, Flemming K, Mclnnes $\mathrm{E}$, et al. Enhancing transparency in reporting the synthesis of qualitative research: ENTREQ. BMC Med Res Methodol 2012;12:181-81.

9 Atkins S, Lewin S, Smith $\mathrm{H}$, et al. Conducting a meta-ethnography of qualitative literature: lessons learnt. BMC Med Res Methodol 2008;8:21.

10 QSR I. NVivo (Version 11), 2015. Available: https://www. qsrinternational.com/nvivo-qualitative-data-analysis-software/home

11 Skaggs RL, Hix E, Huang KE, et al. Characterization of patients quality of life and experience in the course of acne treatment. Skinmed 2017;15:431-5.

12 McNiven A. 'Disease, illness, affliction? Don't know': Ambivalence and ambiguity in the narratives of young people about having acne. Health 2019;23:273-88.

13 Magin P, Adams J, Heading G, et al. The causes of acne: a qualitative study of patient perceptions of acne causation and their implications for acne care. Dermatol Nurs 2006;18:344-70.

14 Ip A, Muller I, Geraghty AWA, et al. Young people's perceptions of acne and acne treatments: secondary analysis of qualitative interview data. Br J Dermatol 2020;183:349-56.

15 Koo J. The psychosocial impact of acne: Patients' perceptions. J Am Acad Dermatol 1995;32:S26-30.

16 Fabbrocini G, Cacciapuoti S, Monfrecola G. A qualitative investigation of the impact of acne on health-related quality of

life (HRQL): development of a conceptual model. Dermatol Ther 2018;8:85-99.

17 Murray CD, Rhodes K. 'Nobody likes damaged goods': the experience of adult visible acne. Br J Health Psychol 2005;10:183-202.

18 Magin P, Adams J, Heading G, et al. Psychological sequelae of acne vulgaris: results of a qualitative study. Can Fam Physician 2006;52:978.

19 Santer M, Chandler D, Lown M, et al. Views of oral antibiotics and advice seeking about acne: a qualitative study of online discussion forums. Br J Dermatol 2017;177:751-7.

20 Pruthi GK, Babu N. Physical and psychosocial impact of acne in adult females. Indian J Dermatol 2012;57:26-9.

21 Jowett S, Ryan T. Skin disease and handicap: an analysis of the impact of skin conditions. Soc Sci Med 1985;20:425-9.

22 Magin P, Adams J, Heading G. 'Perfect skin', the media and patients with skin disease: a qualitative study of patients with acne, psoriasis and atopic eczema, 2011.

23 Magin P, Heading G, Adams J, et al. Sex and the skin: a qualitative study of patients with acne, psoriasis and atopic eczema. Psychol Health Med 2010;15:454-62.

24 Magin P, Adams J, Heading G, et al. Experiences of appearancerelated teasing and bullying in skin diseases and their psychological sequelae: results of a qualitative study. Scand J Caring Sci 2008;22:430-6.

25 Prior J, Khadaroo A. 'I sort of balance it out'. Living with facial acne in emerging adulthood. J Health Psychol 2015;20:1154-65.

26 Magin PJ, Adams J, Heading GS, et al. Patients with skin disease and their relationships with their doctors: a qualitative study of patients with acne, psoriasis and eczema. Med J Aust 2009;190:62-4.

27 Magin PJ, Adams J, Heading GS, et al. Complementary and alternative medicine therapies in acne, psoriasis, and atopic eczema: results of a qualitative study of patients' experiences and perceptions. J Altern Complement Med 2006;12:451-7.

28 Ryskina KL, Goldberg E, Lott B, et al. The role of the physician in patient perceptions of barriers to primary adherence with acne medications. JAMA Dermatol 2018;154:456-9.

29 Magin P, Adams J, Heading G, et al. Patients' perceptions of isotretinoin, depression and suicide--a qualitative study. Aust Fam Physician 2005;34:795-7.

30 Zureigat M, Fildes K, Hammond A, et al. General practitioners' attitudes towards acne management: psychological morbidity and the need for collaboration. Aust J Gen Pract 2019;48:48-52.

31 Do JE, Cho S-M, In S-I, et al. Psychosocial aspects of acne vulgaris: a community-based study with Korean adolescents. Ann Dermatol 2009;21:125-9.

32 Loney T, Standage M, Lewis S. Not just 'skin deep': psychosocial effects of dermatological-related social anxiety in a sample of acne patients. J Health Psychol 2008;13:47-54.

33 Su P, Chen Wee Aw D, Lee SH, et al. Beliefs, perceptions and psychosocial impact of acne amongst Singaporean students in tertiary institutions. J Dtsch Dermatol Ges 2015;13:227-33.

34 Ablett K, Thompson AR. Parental, child, and adolescent experience of chronic skin conditions: a meta-ethnography and review of the qualitative literature. Body Image 2016;19:175-85.

35 Pound P, Britten N, Morgan M, et al. Resisting medicines: a synthesis of qualitative studies of medicine taking. Soc Sci Med 2005:61:133-55.

36 Porter JR, Beuf AH, Lerner A, et al. Psychosocial effect of vitiligo: a comparison of vitiligo patients with "normal" control subjects, with psoriasis patients, and with patients with other pigmentary disorders. J Am Acad Dermatol 1986;15:220-4.

$37 \mathrm{Koo}$ J. Population-Based epidemiologic study of psoriasis with emphasis on quality of life assessment. Dermatol Clin 1996;14:485-96.

38 Jobling RG. Psoriasis -- a preliminary questionnaire study of sufferers' subjective experience. Clin Exp Dermatol 1976;1:233-6.

39 Santer M, Burgess H, Yardley L, et al. Experiences of carers managing childhood eczema and their views on its treatment: a qualitative study. Br J Gen Pract 2012;62:e261-7. 